\title{
OCCURRENCE OF Calodium hepaticum (BANCROFT, 1893) MORAVEC, 1982 EGGS IN FECES OF DOGS AND CATS IN LAGES, SANTA CATARINA, BRAZIL
}

\author{
Rosiléia Marinho de QUADROS(1,2), Paulo Henrique Exterchoter WEISS(2), Luiz Claudio MILETTI(2) \& Anderson Barbosa de MOURA(2)
}

\begin{abstract}
SUMMARY
This study aims to report the incidence of Calodium hepaticum among dogs and cats, pets or stray animals, captured by the Zoonosis Control Center (CCZ) in Lages, Santa Catarina, Brazil. Fecal samples from 108 pet dogs and eight pet cats, and from 357 stray dogs and 97 stray cats, captured by CCZ, were analyzed within the period from July 2010 to November 2012. Coproparasitological exams were performed by techniques of sedimentation, centrifuge-flotation, and simple flotation. Among 465 fecal samples from dogs and 105 from cats, the overall spurious infections for C. hepaticum eggs were $1.05 \%$. For dogs, this positivity was $0.43 \%$ and for cats it was $3.81 \%$. The two positive dogs were stray and out of the four cats, three were stray and one was a pet. Although the occurrence of $C$. hepaticum eggs was low, these data reveal the existence of infected rodents, especially in public places, since, out of the six infected animals, five (83.33\%) were stray. These results are discussed and analyzed with an emphasis on the risk to public health.
\end{abstract}

KEYWORDS: Calodium hepaticum; Pets; Stray animals; Public health.

\section{INTRODUCTION}

Pets play an important role by promoting our well-being; however, they can be hosts of zoonotic parasites, something that increases the relevance of diagnosing gastrointestinal helminths ${ }^{1}$.

Although MORAVEC (1982) has included C. hepatica in the genus Calodium (Calodium hepaticum ${ }^{2}$, this description is rarely used and many authors refer to it as the genus Capillaria ${ }^{3}$. The genus Capillaria is a nematode belonging to the suborder Trichinellina, and to the Capillaridae family ${ }^{4}$. Capillaria can parasitize several vertebrate classes, but four species are observed in human beings: Capillaria phillippinenis, Capillaria plica, Capillaria aerophila, and Capillaria hepatica ${ }^{5}$.

C. hepaticum is the only nematode that parasitizes liver tissue during adult life $\mathrm{e}^{6}$, being diagnosed in many species of mammals such as squirrels, opossums, pigs, rabbits, hares, horses, coyotes, crab-eating foxes, hoary foxes, dogs, cats, primates, and also human beings ${ }^{3,7,8,9,10,11}$.

Adult parasites in the liver are destroyed by inflammatory processes, but the eggs remain in liver tissue. With the death of the animal host (cannibalism, predation, or decay), the eggs of C. hepaticum are released into the environment through feces ${ }^{12}$. Eggs are embryonated in the environment, needing oxygen as well as a period from five to seven weeks at a maximum temperature of $25^{\circ} \mathrm{C}^{6}$.
After infective eggs are ingested, larvae are released into the intestine and they penetrate the intestinal mucosa, fall into the bloodstream, and reach host's liver, where they mature in the space of about one month ${ }^{13}$.

Homeless animals contribute to the spread of eggs, providing a source of infection for other animals and human beings ${ }^{14}$. Due to the fact that primary infection originates from rodents, infection tends to increase, considering the density of these animals in urban areas ${ }^{7}$.

Liver capillariasis in dogs is rare; it is usually diagnosed by means of histopathological exams. Although it is possible to perform the diagnosis by serology, such method is not commercially available. The diagnosis is determined through the morphologic characteristics of bioperculated barrel-shaped eggs with 50-68 $\mu \mathrm{m} \times 28-35 \mu \mathrm{m}^{15}$.

Liver capillariasis is virtually unknown to human medicine, both regarding pathology and diagnosis, and infection may end fatal ${ }^{6}$. Worldwide, 72 cases of human infection have been reported, and most cases in girls under the age of eight ${ }^{4}$.

Parasitic disease in human beings was diagnosed in Europe, Africa, Asia, and the Americas ${ }^{16}$. In Brazil, five cases of liver capillariasis were reported, three in children ${ }^{17}$ and two in adults ${ }^{16}$.

Spurious infections occur due to ingestion of non-embryonated eggs,

(1) Universidade do Planalto Catarinense (UNIPLAC), Av. Castelo Branco, 170 Bairro Universitário, 88509-900 Lages, SC, Brasil. E-mail: rosileia18@ hotmail.com

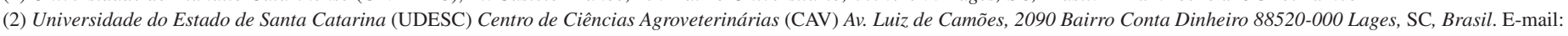
paulohenriqueexterchoterweiss@hotmail.com; luiz.miletti@udesc.br; rosileia18@hotmail.com; anderson.moura@udesc.br

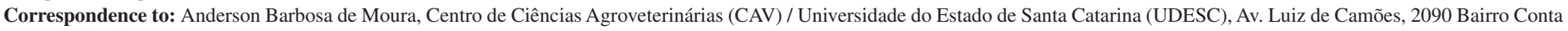
Dinheiro 88520-000 Lages, SC, Brasil. E-mail: anderson.moura@udesc.br 


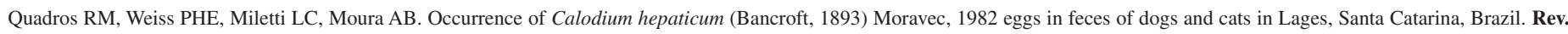
Inst. Med. Trop. Sao Paulo. 2016;58:6.

found on the ground or by eating the liver of mammals infected with C. hepaticum. About 135 cases of spurious infections were reported in literature; 94 of them occurred in Brazil, in the states of Amazonas, Minas Gerais, and Paraná ${ }^{18,19}$. Diagnoses took place mainly in indian tribes, due to the consumption of hunted animals, such as tapir (Tapirus terrestris), white-lipped peccary (Tayasu pecari), and red-faced spider monkey (Ateles pasnicus) $)^{20,21}$.

Diagnosis in living patients is made by means of liver biopsy. However, in most cases, diagnosis is determined through post mortem examination, and the prevalence of parasitosis may be underestimated ${ }^{16}$.

This study aimed to report the presence of $C$. hepaticum eggs in fecal samples from dogs and cats, both pets and stray animals, in Lages, Santa Catarina, Brazil, and warn about the danger of human infection by this parasite.

\section{MATERIALS AND METHODS}

Within the period from July 2010 to December 2011, fecal samples from 108 pet dogs and eight pet cats that were collected weekly from households in eight neighborhoods (São Miguel, Santa Helena, Santa Catarina, Sagrado Coração de Jesus, Guarujá, Caroba, Habitação, and Centenário) in Lages municipality, state of Santa Catarina, southern Brazil. Feces (individual samples) from 357 stray dogs and 97 stray cats were collected from individual stalls at the Zoonosis Control Center (CCZ) of the town, from July 2010 to November 2012. The animal residence time in the $\mathrm{CCZ}$ was found to vary significantly, with an average of six to eight months until their adoption.

Coproparasitological exams were performed by the techniques of sedimentation, centrifugal-flotation and flotation with saturated $\mathrm{NaCl}$ solution (density 1.182). The diagnosis of eggs was performed by visualization with optical microscopy, using enhancement of 100 and 400 times for confirmation. Eggs observed were barrel-shaped, with polar plugs, striation and pores in the outer shell. They were identified as $C$. hepaticum according to FUEHRER et al. (2011) and its size was $50-59 \times 28-33 \mu^{4}$.

\section{RESULTS AND DISCUSSION}

Out of the fecal samples from 465 dogs and 105 cats, spurious infections for $C$. hepaticum eggs (Fig. 1) was observed in six (1.05\%) animals; two $(0.43 \%)$ for dogs and four $(3.81 \%)$ for cats, respectively. Regarding individual populations, only two fecal samples of dogs from $\mathrm{CCZ}$ were positive, a male and a female. Among cats, three were positive for stray cats and one for a pet cat; all three cats were male.

All positive samples were detected by means of the simple flotation and sedimentation techniques, with negative results when undergoing the centrifugal-flotation technique.

The centrifugal-flotation technique is less efficient for diagnosing helminths, while flotation and sedimentation methods are more effective for this diagnosis 22 . Using a greater amount of feces in the sedimentation technique, when compared to others, allows a satisfactory and safe diagnosis even when low amounts of parasitic structures are present $^{23}$.

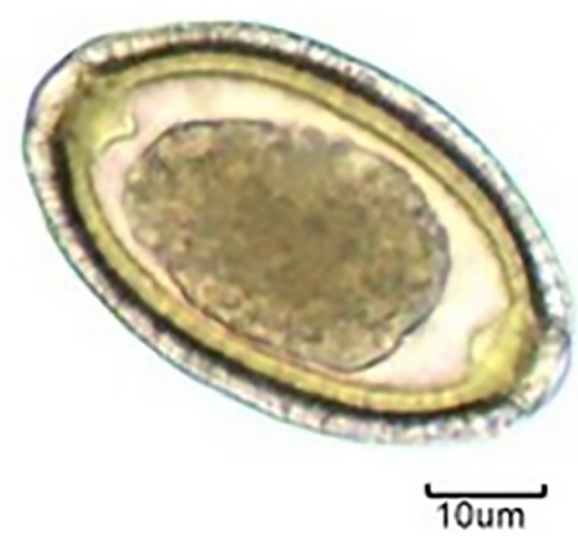

Fig. 1 - Calodium hepaticum egg in dog feces, by simple fluctuation technique detected in Lages, SC, 2013. (400X). Source: Prepared by the authors.

Spurious infections in pets and stray animals indicate dispersal of unembryonated eggs to human settings and there is a risk for humans to get infected (e.g. pica $=$ children eating sand). Although the occurrence of $C$. hepaticum eggs was low, these data suggested the existence of infected rodents, especially in public places, since most (5/6) animals positive for the parasite were stray dogs and cats captured by CCZ, suggesting the existence of appropriate conditions for the transmission of this nematode, but the role played by this type of infection to maintain the parasite cycle is unknown ${ }^{20}$.

C. hepaticum has a cosmopolitan distribution and it is highly prevalent in mice, thus it is believed that several cases are not detected, explaining the low notification rates of this disease $\mathrm{e}^{17}$.

The animals whose feces had eggs were adult and predominantly male (5/6), corroborating the data provided by RUAS et al. (2003) in a study on Capillaria spp. conducted with wild carnivores in Rio Grande do Sul State, where, according to the authors, there is a correlation between age (adults) and gender (males) regarding the prevalence of this parasite ${ }^{11}$.

The highest occurrence of $C$. hepaticum eggs in cat feces may be due to the fact that they, even as pets, go out to hunt, mainly rodents, and predation contributes to the spread of eggs in the environment ${ }^{14}$.

In Brazil, C. hepaticum eggs were diagnosed in $\operatorname{dog}^{14,24,25}$ and in cat feces ${ }^{14,26}$, as well as eggs and liver disease have been reported for several wild mammal species: rodents belonging to the genus Cavia sp., Sciuris aestuans (Brazilian squirrel), Cuniculus paca (paca), Pecari tajucu (collared peccary), Tayassu pecari (white-lipped peccary), Tapirus terrestris (tapir), Cerdocyon thous (crab-eating fox), Lycalopex gymnocercus (pampas fox), Chrysocyon brachyurus (maned wolf), and Puma concolor (cougar) ${ }^{8}$.

The high prevalence of this parasite in rodents, especially in brown rats (Rattus norvegicus), house mice (Mus musculus), and black rats (Rattus rattus), suggests that these animals are their primary hosts ${ }^{14}$ (ILHA; BARROS, 2000). The infection rate for rodents may vary from $0.2 \%$ to $88 \%$, with higher prevalence for $R$. norvegicus ${ }^{15}$.

The rapid proliferation of rodents, combined with lack of control 
planning, along with the presence of parasitic infection in rat species, favorable environmental conditions and exposed populations constitute factors that can ultimately pose risks to human health ${ }^{7}$.

Experimentally, C. hepaticum eggs remain viable in the environment for up to 25 months and they can become embryonated and cause infection for up to 681 days in a mouse's liver; they can remain viable for up to 750 days at the temperature of $8^{\circ} \mathrm{C}$ and for up to 60 days at $15^{\circ} \mathrm{C}^{27}$. These data are important in the epidemiology of this parasitosis, mainly because in the town of Lages the average annual temperature is $17^{\circ} \mathrm{C}$, while in winter the average temperature is $11^{\circ} \mathrm{C}^{28}$. These conditions may favor the transmission cycle of the nematode.

The zoonotic nature of $C$. hepaticum requires special attention from animal handlers at zoos, who must avoid contact with soil or enclosures containing fecal content of carnivores ${ }^{29}$. Therefore, places such as CCZ should also take this particular action when cleaning kennels or catteries, as well as children when playing in public environments with fecal material.

Human capillariasis may become fatal ${ }^{13}$ and its in vivo diagnosis is difficult. Considering that this is a parasitic disease that occurs in a wide variety of mammals and has rodents as primary hosts, it is worth disclosing information about it, since the growth of human population, especially in big cities, combined with the accumulation of waste and the increased population of rodents and homeless animals can increase the risk to human health, especially in the outskirts of cities.

\section{REFERENCES}

1. Moraes AS, Claudino D, Name JVF, Carneiro LS, Vieira LA, Mendes DS. Ocorrência de parasitos zoonóticos em fezes de cães provenientes de uma entrequadra da Asa Norte de Brasília, DF. Universitas Ciênc Saúde. 2009;7:19-27.

2. Moravec F. Proposal of a new systematic arrangement of nematodes of the family Capillariidae. Folia Parasitol(Praha). 1982;29:119-32.

3. Fuehrer HP. An overview of the host spectrum and distribution of Calodium hepaticum (syn. Capillaria hepatica): part 1-Muroidea. Parasitol Res. 2014; 113:619-40.

4. Fuehrer HP, Igel P, Auer H. Capillaria hepatica in man an overview of hepatic capillariosis and spurious infection. Parasitol Res. 2011;109:969-79.

5. Bair MJ, Hwang KP, Wang TE, Liou TC, Lin SC, Kao CR, et al. Clinical features of human intestinal capillariasis in Taiwan. World J Gastroenterol. 2004;10:2391-3.

6. Mowat V, Turton J, Stewart J, Lui KC, Pilling AM. Histopathological features of Capillaria hepatica infection in laboratory rabbits. Toxicol Pathol. 2009;37:661-6.

7. Duque BA, Aranzazu D, Agudelo-Flórez P, Londoño AF, Quiroz VH, Rodas JD. Rattus norvegicus como indicador de la circulación de Capillaria hepatica y Taenia taeniaeformis em la Plaza Minorista de Medellín, Colombia. Biomédica. 2012;32:5108.

8. Fuehrer HP. An overview of the host spectrum and distribution of Colodium hepaticum (syn. Capillaria hepatica): part 2-Mammalia (excluding Muroidea). Parasitol Res. 2014;113:641-51.

9. Munroe GA. Pyloric stenosis in yearling with an incidental finding of Capillaria hepatica in the liver. Equine Vet J. 1984;16:221-2.

10. Pizzi R, Gordon JC, Flach EJ, Routh AD, Clark B, Boardman WSJ. Capillaria hepatica (syn. Calodium hepaticum) in primates in a zoological collection in the UK. Vet Rec. 2008;163:690-1.
11. Ruas JL, Soares MP, Farias NAR, Brun JGW. Infecção por Capillaria hepatica em carnívoros silvestres (Lycalopex gymnocercus e Cerdocyon thous) na região sul do Rio Grande do Sul. Arq Inst Biol. 2003;70:127-30.

12. Govil H, Desai M. Capillaria hepatica parasitism. Indian J Pediatr. 1996;63:698-700.

13. Acha PN, Szyfres B. Zoonoses and communicable diseases common to man and animals Parasitoses. 3 ed. Washington: PAHO; 2003. v.3

14. Ilha MRS, Barros CSL. Capilariose hepática em cães e gatos: 15 casos. Ciênc Rural 2000;30:665-9.

15. Lloyd S, Elwood CM, Smith KC. Capillaria hepatica (Colodium hepaticum) infection in a British dog. Vet Rec. 2002;151:419-20.

16. Juncker-Voss M, Prosl H, Lussy H, Enzenberg U, Auer H, Nowotny N. Serological detection of Capillaria hepatica by indirect immunofluorescence assay. J Clin Microbiol. 2000;38:431-3.

17. Sawamura R, Fernandes MIM, Peres LC, Galvão LC, Goldani HAS, Jorge SM, et al Hepatic capillariasis in children: report of 3 cases in Brazil. Am J Trop Med Hyg. 1999;61:642-7.

18. Carvalho-Costa FA, Silva AG, De Souza AH, Moreira CJ, De Souza DL, Valverde JG, et al. Pseudoparasitism by Calodium hepaticum (syn. Capillaria hepatica, Hepaticola hepatica) in the Negro River, Brazilian Amazon. Trans R Soc Trop Med Hyg. 2009; 103:1071-3

19. Klisiowicz DR, Reifur L, Shimada MK, Haidamak J, Cognialli RCR, Ferreira T. High occurrence of Calodium hepaticum (syn. Capillaria hepatica) spurious infection in a village in the Atlantic Forest of southern Brazil. Mem Inst Oswaldo Cruz. 2014;109:371-3

20. Gonçalves AQ, Ascaso C, Santos I, Serra PT, Julião GR, Orlandi PP. Calodium hepaticum: household clustering transmission and the finding of a source of human spurious infection in a community of the Amazon region. Plos Negl Trop Dis. 2012;6:e1943.

21. Soares MCP, Nunes HM, Silveira FAA, Alves MM, Souza AJS. Capillaria hepatica (Bancroft, 1893) (Nematoda) entre populações indígenas e mamíferos silvestres no noroeste do estado do Mato Grosso, Brasil, 2000. Rev Pan-Amaz Saúde. 2011;2:35-40.

22. Táparo C, Perri SHV, Serrano ACM, Ishizaki MN, Costa TP, Amarante AFT, et al. Comparação entre técnicas coproparasitológicas no diagnóstico de ovos de helmintos e oocistos de protozoários em cães. Rev Bras Parasitol Vet. 2006;15:1-5.

23. De Carli GA. Parasitologia clínica: seleção de métodos e técnicas de laboratório para o diagnóstico de parasitoses em humanos. 2 ed. São Paulo: Atheneu; 2008.

24. Palma HE, Basso PC, Amaral AS, Silva AP, Silva CF. Parasitismo por Colodium hepaticum em dois cães. Ciênc Rural. 2009;39:2642-5.

25. Vasconcellos MC, Barros JSL, Oliveira CS. Parasitas gastrointestinais em cães institucionalizados no Rio de Janeiro, RJ. Rev Saúde Pública. 2006;40:321-3.

26. Pivoto FL, Lopes LFD, Vogel FSF, Botton SA, Sangioni L.A. Ocorrência de parasitos gastrintestinais e fatores de risco de parasitismo em gatos domésticos urbanos de Santa Maria, RS, Brasil. Ciênc Rural. 2013;43:1453-8.

27. Galvão VA. Estudos sobre Capillaria hepatica: uma avaliação do seu papel patogênico para o homem. Mem Inst Oswaldo Cruz. 1981;76:415-33.

28. Santa Catarina. Empresa de Pesquisa Agropecuária e Extensão Rural de Santa Catarina (EPAGRI) Relatório meteorológico. Lages: Epagri; 2013.

29. Redrobe SP, Petterson-Kane JC. Calodium hepaticum (syn. Capillaria hepatica) in captive rodents in a zoological garden. J Comp Pathol. 2005;133:73-6.

Received: 04 March 2015

Accepted: 13 April 2015 